\title{
Mourning our dead in the covid-19 pandemic
}

\author{
Covid-19 is having an impact on how we bury and mourn our dead
}

\section{Seamus O'Mahony retired gastroenterologist and visiting professor}

Centre for the Humanities and Health, King's College London, UK

I came back to Ireland in 2001, after working for 14 years in the NHS. I had underestimated the re-acclimatisation involved in this move. The most striking cultural difference between Britain and Ireland is how we mourn and bury our dead. In Britain, funerals are private affairs; in Ireland they are communal events. I attended only one funeral during my 14 years living in Scotland and England; when I came back to Ireland, I found myself regularly queueing at removals.

Ritual comforts the bereaved and guides the words ("sorry for your trouble") and behaviour of mourners. Kevin Toolis's $M y$ Father's Wake (2017) is a lyrical account of how the old customs are still treasured in the almost Homeric community of Achill island, off the west coast of Ireland. We Irish are famous for our wakes. Many of the rituals (and "games") associated with wakes were pre-Christian in origin; by the nineteenth century, wakes had become such Dionysian extravaganzas that the Catholic hierarchy tried to ban them.

Wakes have become increasingly uncommon, but the old funeral customs - the traditional sequence of rosary, removal, funeral mass, and burial—are still adhered to in rural Ireland. In the cities, these customs are slowly withering, victims of secularism and atomisation. The Catholic church, once the pre-eminent force in the country, saw its power collapse over a single generation. The Celtic Tiger years showed that the Irish weren't quite as mystical, spiritual, or, well, Celtic as we had led the world to believe. We could do greed and materialism with the best of them.

More than $90 \%$ of the population in the Irish Republic is nominally Catholic, but now fewer than half regularly attend mass. Vocations to the priesthood have plummeted; the average age of Catholic priests in Ireland is now 70. Priests from Kerala, Nigeria, the Philippines, and Uganda have come to work in Ireland: in a bizarre historical reversal, we have become a mission country. We may not go to mass anymore, but we still call on the Church for the big events: birth, marriage, and death-particularly death.

Which brings me to the covid-19 pandemic. On 31 March, the Irish government announced new regulations on the conduct of funerals, burials, and cremations: "Immediate family members can still attend funeral services, burials, and cremations, provided that social distancing rules are respected. This relates to all funerals, including those arising out of covid-19 deaths. While we know this is difficult, in general, numbers attending should not exceed 10 persons in places of worship and at the graveside." Many Irish priests-including five bishops-are over 70 and are cocooned. Some bishops have recommended a policy of praying at the graveside only, with the funeral mass held behind closed doors without a congregation. Those dying from covid-19 are often buried without close family members present, as they must self-isolate after contact with the dying person.

A Scottish friend emailed me recently, saying he was perplexed and intrigued by the public's general acceptance of increasingly stringent restrictions on basic civil liberties such as the right to assemble. Worse, in his view, was the deprivation of rights surrounding death and dying. He was in favour of informed consent for the public to participate in these activities, lest their denial be "the straw that breaks the back of social cohesion." $\mathrm{He}$ asked me whether the Irish were in rebellion against these restrictions. Bereaved families have certainly spoken of their heartbreak, how shaken, angry, and hurt they have been by the loss of the comforting rituals and the contact with the dead person. But none has talked of defying these restrictions. There is an acceptance, both among the bereaved and in society at large, that there is no alternative. They are angry with the virus, not the government. Public good comes before private grief.

The Irish have had to find new ways of mourning. On 20 March, in Ballyferriter, a remote village in the Dingle Peninsula, the entire parish, each person observing correct social distancing, lined the $2 \mathrm{~km}$ road to the graveyard to honour Betty Ryan. Funeral masses are being live streamed. Well wishers can post their condolences on funeral websites; social media has suddenly become a force for good. The situation will eventually end, and then the bereaved can publicly mourn. But deferred mourning can never be quite the same. Bereavement counsellors are predicting a delayed epidemic of pathological grief and depression.

Many of us are hoping that the post-covid world will be a better, kinder, less frenetic place. We hope for a new way of living with each other and with the finite resources of this planet. Having been temporarily deprived, we might once again come 
to value the creatureliness of mourning rituals and the embrace of community.

Competing interests: None declared

\section{Commissioned, not peer reviewed}

Published by the BMJ Publishing Group Limited. For permission to use (where not already granted under a licence) please go to http://group.bmj.com/group/rights-licensing/ permissions 